\title{
Effects of Intake of Fish or Fish Oils on the Development of Diabetes
}

\author{
Hidekatsu Yanai $^{\text {a, b }}$, Hidetaka Hamasakia ${ }^{a}$ Hisayuki Katsuyama ${ }^{a}$, Hiroki Adachia ${ }^{a}$, Sumie Moriyama ${ }^{a}$, \\ Akahito Sako ${ }^{a}$
}

\begin{abstract}
The association between fish and fish oils intake and diabetes remains largely unknown. Here we systematically reviewed published articles (clinical trials, prospective cohort studies, systematic reviews and meta-analyses) about the effects of intake of fish or fish oils on the development of diabetes. An intake of fish oils seems not to affect insulin sensitivity, insulin secretion, beta-cell function or glucose tolerance. There is a considerable statistical heterogeneity in the overall summary estimates of the association between fish or fish oils consumption and the development of type 2 diabetes, which is partly explained by geographical differences. Marine n-3 polyunsaturated fatty acids have beneficial effects on the prevention of type 2 diabetes in Asian populations.
\end{abstract}

Keywords: Diabetes; Docosahexaenoic acid; Eicosapentaenoic acid; Fish; Insulin sensitivity

\section{Introduction}

Epidemiological and clinical studies indicate a significant inverse association between intake of fish oils, eicosapentaenoic acid (EPA) and docosahexaenoic acid (DHA), and mortality associated with coronary artery disease [1-6]. Secondary prevention trials reported that increased consumption of fish or fish-oil supplements reduced coronary death in post-infarction patients $[7,8]$. The proposed anti-atherosclerotic properties of EPA include reduction of platelet aggregation [9], amelioration of endothelial dysfunction [10], suppression of the proliferation of vascular smooth muscle cells [11], stabilization of fatty

Manuscript accepted for publication September 09, 2014

aDepartment of Internal Medicine, National Center for Global Health and Medicine Kohnodai Hospital, Chiba, Japan

${ }^{b}$ Corresponding Author: Hidekatsu Yanai, Department of Internal Medicine, National Center for Global Health and Medicine Kohnodai Hospital, 1-7-1 Kohnodai, Chiba 272-8516, Japan. Email: dyanai@hospk.ncgm.go.jp

doi: http://dx.doi.org/10.14740/jocmr1964w plaque [12] and reduction of fasting blood triglyceride [13].

Evidences to show beneficial effects of fish oils on atherosclerotic diseases have been accumulating; however, the association between fish or fish oils intake and diabetes remains largely unknown. Here we systematically reviewed published articles about the effects of intake of fish or fish oils on the development of diabetes.

\section{Clinical Trials and Prospective Cohort Studies to Show Effects of Intake of Fish or Fish Oils on the Development of Diabetes}

Clinical trials and prospective cohort studies about effects of intake of fish or fish oils on the development of diabetes were shown in Table 1 [14-20]. Giacco et al performed the clinical trial to evaluate the effect of a moderate supplementation of long-chain n-3 fatty acids (FA) on insulin sensitivity, insulin secretion, beta-cell function and glucose tolerance in healthy individuals [14]. One hundred sixty-two healthy individuals were randomly assigned to diets rich in monounsaturated fats and the other rich in saturated fats for 3 months. Within each group there was a second randomization to fish oil (n-3 FA $3.6 \mathrm{~g} /$ day) or placebo. A moderate supplementation of fish oil did not affect insulin sensitivity, insulin secretion, beta-cell function or glucose tolerance. Griffin et al studied the effect of dietary ratio of n-6 to n-3 (n-6:n-3) polyunsaturated fatty acids (PUFA) on metabolic parameters [15]. In a randomized, parallel design in 258 subjects aged 45 - 70 years old, four diets providing $6 \%$ of energy as PUFA with an $n-6: n-3$ between $5: 1$ and $3: 1$ with a control diet that had an $n-6: n-3$ of $10: 1$ were compared. Changes in the $n-6: n-3$ did not influence insulin sensitivity.

Brostow et al examined the association between total omega-3 FA, EPA, DHA, $\alpha$-linolenic acid, and omega-6 FA and omega-6:omega-3 ratio and risk of type 2 diabetes in a Chinese population in Singapore [16]. Intake of omega-3 FA from marine sources (EPA and DHA) was not associated with diabetes risk. Villegas et al performed a prospective population-based cohort study in 51,963 men and 64,193 women free of type 2 diabetes, cardiovascular diseases, and cancer, to examine the associations between fish, shellfish, and long-chain n-3 FA and the risk of type 2 diabetes in a middle-aged Chinese population [17]. Fish, shellfish, and long-chain n-3 FA intakes were 
Table 1. Clinical Trials and Prospective Cohort Studies to Show Effects of Intake of Fish or Fish Oils on the Development of Diabetes

\begin{tabular}{|c|c|c|c|}
\hline Authors & Study design & Subjects studied & Results/conclusions \\
\hline Giacco et al [14] & $\begin{array}{l}\text { Healthy individuals were randomly } \\
\text { assigned to monounsaturated fats } \\
\text { and the other rich in saturated } \\
\text { fats for } 3 \text { months. Within each } \\
\text { group there was a second rand- } \\
\text { omization to fish oil (n-3 fatty } \\
\text { acids } 3.6 \mathrm{~g} \text { /day) or placebo. }\end{array}$ & $\begin{array}{l}162 \text { healthy individuals. } \\
\text { Performed in Sweden. }\end{array}$ & $\begin{array}{l}\text { A moderate supplementation of } \\
\text { fish oil does not affect insulin sen- } \\
\text { sitivity, insulin secretion, beta-cell } \\
\text { function or glucose tolerance. }\end{array}$ \\
\hline Villegas et al [17] & $\begin{array}{l}\text { A prospective population-based co- } \\
\text { hort study. A Cox regression model } \\
\text { was used to evaluate the association } \\
\text { of fish, shellfish, and long-chain n- } 3 \\
\text { FA with risk of type } 2 \text { diabetes. }\end{array}$ & $\begin{array}{l}51,963 \text { Chinese men and } \\
64,193 \text { Chinese women free } \\
\text { of type } 2 \text { diabetes, cardiovas- } \\
\text { cular diseases, and cancer. }\end{array}$ & $\begin{array}{l}\text { An inverse association between } \\
\text { fish and shellfish intake and type } 2 \\
\text { diabetes in women was found. }\end{array}$ \\
\hline Djousse et al [18] & $\begin{array}{l}\text { A prospective study. Incident type } \\
2 \text { diabetes was self-reported and } \\
\text { validated primarily through the } \\
\text { collection of supplementary infor- } \\
\text { mation from participants. Informa- } \\
\text { tion on omega-3 and fish intakes } \\
\text { was obtained by using a validated } \\
\text { food-frequency questionnaire. Cox } \\
\text { proportional hazard models were } \\
\text { used to estimate adjusted RR. }\end{array}$ & $\begin{array}{l}36,328 \text { women (mean age: } 54.6 \\
\text { years old) who participated in } \\
\text { the Women's Health Study and } \\
\text { who were followed from } 1992 \\
\text { to } 2008 \text {. Performed in USA. }\end{array}$ & $\begin{array}{l}\text { An increased risk of type } 2 \text { diabetes with } \\
\text { the intake of long-chain omega- } 3 \text { FA, } \\
\text { especially with higher intakes ( } \geq 0.20 \mathrm{~g} \\
\text { omega-3/day or } \geq 2 \text { servings of fish/day). }\end{array}$ \\
\hline $\begin{array}{l}\text { Van Wouden- } \\
\text { bergh et al [19] }\end{array}$ & $\begin{array}{l}\text { A population-based cohort. } \\
\text { Hazard ratios (RR) with } 95 \% \text { CIs } \\
\text { were used to examine risk as- } \\
\text { sociations adjusted for age, sex, } \\
\text { lifestyle, and nutritional factors. }\end{array}$ & $\begin{array}{l}4,472 \text { Dutch participants aged } \geq \\
55 \text { years old without diabetes. }\end{array}$ & $\begin{array}{l}\text { A beneficial effect of total fish, type of } \\
\text { fish, or EPA and DHA intake on the risk } \\
\text { of type } 2 \text { diabetes was not observed. }\end{array}$ \\
\hline Djousse et al [20] & $\begin{array}{l}\text { Plasma phospholipid n-3 FA were } \\
\text { measured by using gas chromatog- } \\
\text { raphy, and incident diabetes was } \\
\text { ascertained by using information } \\
\text { on hypoglycemic agents and serum } \\
\text { glucose. Cox proportional haz- } \\
\text { ards models were used to estimate } \\
\text { multivariable-adjusted relative risks. }\end{array}$ & $\begin{array}{l}\text { 3,088 older men and women } \\
\text { (mean age: } 75 \text { years old) from } \\
\text { the Cardiovascular Health Study } \\
(1992-2007) . \text { Performed in USA. }\end{array}$ & $\begin{array}{l}\text { Long-chain n-3 FA were not associated } \\
\text { with a higher incidence of diabetes. }\end{array}$ \\
\hline
\end{tabular}

ALA: $\alpha$-linolenic acid; CI: confidence interval; DHA: docosahexaenoic acid; EPA: eicosapentaenoic acid; FA: fatty acids; PUFA: polyunsaturated fatty acids; RR: relative risk. 
Table 2. Meta-Analyses to Show Effects of Intake of Fish or Fish Oils on the Development of Diabetes

\begin{tabular}{|c|c|c|c|}
\hline Authors & Study design & Subjects studied & Results/Conclusions \\
\hline Akinkuolie et al [21] & $\begin{array}{l}\text { To systematically review the } \\
\text { effect of n-3 PUFA on insu- } \\
\text { lin sensitivity by conducting a } \\
\text { meta-analysis of available RCTs. } \\
\text { MEDLINE, EMBASE, CEN- } \\
\text { TRAL and clinicaltrials.gov from } \\
\text { the beginning of each database } \\
\text { until October } 2010 \text { were used. }\end{array}$ & $\begin{array}{l}\text { Eleven RCTs }(n=618) \text { were eligible } \\
\text { for inclusion in the analysis. }\end{array}$ & $\begin{array}{l}\text { This meta-analysis is consist- } \\
\text { ent with a lack of n-3 PUFA } \\
\text { effects on insulin sensitivity. }\end{array}$ \\
\hline Wallin et al [22] & $\begin{array}{l}\text { To find the evidence on the } \\
\text { association between fish con- } \\
\text { sumption, dietary long-chain n-3 } \\
\text { FA, and risk of type } 2 \text { diabetes, } \\
\text { studies were identified by search- } \\
\text { ing the PubMed and EMBASE } \\
\text { databases through December } 15 \text {, } \\
2011 \text { and by reviewing the refer- } \\
\text { ence lists of retrieved articles. }\end{array}$ & $\begin{array}{l}\text { Sixteen studies involving } 527,441 \\
\text { participants and } 24,082 \text { dia- } \\
\text { betes cases were included. }\end{array}$ & $\begin{array}{l}\text { For each serving per week } \\
\text { increment in fish consumption, } \\
\text { the RRs ( } 95 \% \text { CIs) of type } \\
2 \text { diabetes were } 1.05(1.02 \text { - } \\
1.09), 1.03(0.96-1.11) \text {, and } \\
0.98(0.97-1.00) \text { combining } \\
\text { US, European, and Asian/ } \\
\text { Australian studies, respec- } \\
\text { tively. For each } 0.30 \text { g per day } \\
\text { increment in long-chain n-3 } \\
\text { FA, the corresponding sum- } \\
\text { mary estimates were } 1.17 \text { (1.09 } \\
-1.26), 0.98(0.70-1.37) \text {, and } \\
0.90(0.82-0.98), \text { respectively. }\end{array}$ \\
\hline Zheng et al [23] & $\begin{array}{l}\text { A systematic review and meta- } \\
\text { analysis of prospective cohort } \\
\text { studies to examine the associa- } \\
\text { tions of fish and n-3 PUFA intake } \\
\text { with type } 2 \text { diabetes risk. }\end{array}$ & $\begin{array}{l}\text { PubMed, Embase, Cochrane library, } \\
\text { China National Knowledge Infra- } \\
\text { structure (CNKI) and Chinese VIP } \\
\text { database up to January } 2012 \text { were } \\
\text { used to identify relevant studies. }\end{array}$ & $\begin{array}{l}\text { Marine n- } 3 \text { PUFA have } \\
\text { beneficial effects on the } \\
\text { prevention of type } 2 \text { diabe- } \\
\text { tes in Asian populations. }\end{array}$ \\
\hline Wu et al [24] & $\begin{array}{l}\text { Systematically search for multiple } \\
\text { literature databases through June } \\
2011 \text { to identify prospective studies } \\
\text { examining relations of dietary n-3 } \\
\text { PUFA, dietary fish and/or seafood, } \\
\text { and circulating n-3 PUFA biomark- } \\
\text { ers with incidence of diabetes. }\end{array}$ & $\begin{array}{l}\text { Sixteen studies including } 18 \\
\text { separate cohorts comprising } \\
540,184 \text { individuals and } 25,670 \\
\text { cases of incident diabetes. }\end{array}$ & $\begin{array}{l}\text { The overall pooled findings } \\
\text { do not support either major } \\
\text { harms or benefits of fish/ } \\
\text { seafood or EPA + DHA on } \\
\text { development of diabetes. }\end{array}$ \\
\hline
\end{tabular}

Cl: confidence interval; DHA: docosahexaenoic acid; EPA: eicosapentaenoic acid; FA: fatty acids; PUFA: polyunsaturated fatty acids; RCT: randomized controlled trial.

inversely associated with type 2 diabetes in women. The relative risks (RRs $(95 \% \mathrm{CI})$ ) for quintiles of fish intake were 1.00 , 0.96 (0.86 - 1.06), 0.84 (0.75 - 0.94), 0.80 (0.71 - 0.90), and $0.89(0.78-1.01)(\mathrm{P}$ for trend $=0.003)$ and for shellfish were $1.00,0.91$ (0.82 - 1.01), 0.79 (0.71 -0.89), 0.80 (0.71 - 0.91), and $0.86(0.76-0.99)(P=0.006)$. In men, only the association between shellfish intake and type 2 diabetes was significant. The RRs $(95 \%$ CI) for quintiles of fish intake were $1.00,0.92$ (0.75 - 1.13), 0.80 (0.65 - 1.00), 0.89 (0.72 - 1.11), and 0.94 $(0.74-1.17)(\mathrm{P}$ for trend $=0.50)$ and for shellfish intake were $1.00,0.93$ (0.76 - 1.12), 0.70 (0.56 - 086), 0.66 (0.53 - 0.82), and $0.82(0.65-1.02)(\mathrm{P}$ for trend $=0.003)$.

Djousse performed a prospective study of 36,328 women (mean age: 54.6 years old) who participated in the Women's Health Study and who were followed from 1992 to 2008, to evaluate effects of dietary omega-3 FA and fish consumption on the risk of type 2 diabetes [18]. From the lowest to highest quintiles of marine omega- 3 intake, the multivariable-adjusted hazard ratios $(95 \% \mathrm{CIs})$ for type 2 diabetes were 1.0 (referent), 1.17 (1.03 - 1.33), 1.20 (1.05 - 1.38), 1.46 (1.28 - 1.66), and $1.44(1.25-1.65)$, respectively ( $\mathrm{P}$ for trend $<0.0001)$, suggesting an increased risk of type 2 diabetes with the intake of long-chain omega-3 FA, especially with higher intakes $(\geq 0.20$ g omega-3 FA/day or $\geq 2$ servings of fish/day). Van Woudenbergh et al investigated the relation between total fish, type of fish (lean and fatty), and EPA and DHA intake and risk of type 2 diabetes in a population-based cohort study, by the analysis including 4,472 Dutch participants aged $\geq 55$ years old without diabetes [19]. Total fish intake was positively associated with risk of type 2 diabetes; the RR was 1.32 (95\% CI 1.02 - 1.70) in the highest total fish group ( $\geq 28 \mathrm{~g} /$ day) compared with that for non-fish eaters ( $\mathrm{P}$ for trend $=0.04$ ). Lean fish intake tended to be associated positively with the development of type 2 diabetes (RR highest group ( $\geq 23 \mathrm{~g}$ /day) 1.30 (95\% CI 1.01 - 1.68), P for trend $=0.06$ ), but fatty fish was not. No association was observed between EPA and DHA intake and type 2 
diabetes. Djousse et al examined the relation between plasma phospholipid n-3 FA and incident diabetes, by the analysis of 3,088 older men and women (mean age: 75 years old) from the Cardiovascular Health Study (1992 - 2007) [20]. Long-chain n-3 FA was not associated with a higher incidence of diabetes.

\section{Meta-Analyses Investigating the Effects of In- take of Fish or Fish Oils on the Development of Diabetes}

Meta-analyses about effects of intake of fish or fish oils on the development of diabetes were shown in Table 2 [21-24]. Akinkuolie et al systematically reviewed the effect of $n-3$ PUFA on insulin sensitivity by conducting a meta-analysis of available randomized controlled trials (RCTs) [21]. Eleven RCTs $(n=618)$ were eligible for inclusion in the analysis. In a pooled estimate, n-3 PUFA intervention had no effects on insulin sensitivity compared to placebo.

Wallin et al performed a systematic review and metaanalysis to understand the association between fish consumption, dietary n-3 FA, and risk of type 2 diabetes, by searching the PubMed and EMBASE databases through December 15, 2011 [22]. Sixteen studies involving 527,441 participants and 24,082 diabetes cases were included. Considerable statistical heterogeneity in the overall summary estimates was partly explained by geographical differences. For each serving per week increment in fish consumption, the RRs (95\% CIs) of type 2 diabetes were 1.05 (1.02 - 1.09), 1.03 (0.96 - 1.11), and $0.98(0.97-1.00)$, in combined analysis of studies performed in US, European, and Asian/Australian, respectively. For each $0.30 \mathrm{~g}$ per day increment in long-chain n-3 FA, the corresponding summary estimates were 1.17 (1.09 - 1.26), 0.98 (0.70 $1.37)$, and 0.90 (0.82 - 0.98). This meta-analysis indicated differences between geographical regions in observed associations of fish consumption and dietary intake of long-chain n-3 FA with risk of type 2 diabetes. Zheng et al conducted a systematic review and meta-analysis of prospective cohort studies to examine the associations of fish and n-3 PUFA intake with type 2 diabetes risk [23]. Twenty-four studies including 24,509 type 2 diabetic patients and 545,275 participants were identified. For cohort studies, the summary RR of type 2 diabetes for the highest vs. lowest categories of total fish and marine n-3 PUFA intake was 1.07 (95\% CI: 0.91 - 1.25) and 1.07 (95\% CI: $0.95-1.20)$, respectively. Subgroup analyses indicated that summary RR (highest vs. lowest category) of type 2 diabetes for fish and marine n-3 PUFA intake was 0.89 (95\% CI: 0.81 - 0.98) and 0.87 (95\% CI: 0.79 - 0.96) for Asian populations, and 1.20 (95\% CI: 1.01 - 1.44) and 1.16 (95\% CI: $1.04-1.28)$ for Western populations. This systematic review and metaanalysis showed that marine n-3 PUFA have beneficial effects on the prevention of type 2 diabetes in Asian populations. Wu et al systematically searched multiple literature databases through June 2011 to identify prospective studies examining relations of dietary n-3 PUFA, dietary fish and/or seafood, and circulating n-3 PUFA biomarkers with incidence of diabetes [24]. Sixteen studies met inclusion criteria, including 18 separate cohorts comprising 540,184 individuals and 25,670 cases of incident diabetes. Consumption of fish and/or seafood was not significantly associated with diabetes $(\mathrm{n}=13$ studies; RR per $100 \mathrm{~g} /$ day $=1.12,95 \% \mathrm{CI}=0.94-1.34)$, nor was consumption of EPA + DHA ( $\mathrm{n}=16$ cohorts; RR per $250 \mathrm{mg} /$ day $=1.04,95 \% \mathrm{CI}=0.97-1.10)$ nor circulating levels of EPA + DHA biomarkers $(n=5$ cohorts; RR per $3 \%$ of total fatty acids $=0.94,95 \% \mathrm{CI}=0.75-1.17)$. In unadjusted meta-regressions, study location (Asia vs. North America/Europe), mean BMI, and duration of follow-up each modified the association between fish/seafood and EPA + DHA consumption and DM risk (P-interaction $\leq 0.02$ each).

\section{Conclusion}

An intake of fish oils seems not to affect insulin sensitivity, insulin secretion, beta-cell function or glucose tolerance. There is a considerable statistical heterogeneity in the overall summary estimates of the association between fish consumption, dietary long-chain n-3 FA, and risk of type 2 diabetes, which is partly explained by geographical differences. Marine n-3 PUFA have beneficial effects on the prevention of type 2 diabetes in Asian populations.

\section{Acknowledgement}

This work was supported by a grant from the National Center for Global Health and Medicine (26-112).

\section{Conflict of Interests}

The authors declare that they have no competing interests.

\section{References}

1. Kromhout D, Bosschieter EB, de Lezenne Coulander C. The inverse relation between fish consumption and 20year mortality from coronary heart disease. N Engl J Med. 1985;312(19):1205-1209.

2. Siscovick DS, Raghunathan TE, King I, Weinmann S, Wicklund KG, Albright J, Bovbjerg V, et al. Dietary intake and cell membrane levels of long-chain n-3 polyunsaturated fatty acids and the risk of primary cardiac arrest. JAMA. 1995;274(17):1363-1367.

3. Daviglus ML, Stamler J, Orencia AJ, Dyer AR, Liu K, Greenland P, Walsh MK, et al. Fish consumption and the 30-year risk of fatal myocardial infarction. N Engl J Med. 1997;336(15):1046-1053.

4. Albert CM, Hennekens CH, O'Donnell CJ, Ajani UA, Carey VJ, Willett WC, Ruskin JN, et al. Fish consumption and risk of sudden cardiac death. JAMA. 1998;279(1):2328.

5. Hu FB, Bronner L, Willett WC, Stampfer MJ, Rexrode KM, Albert CM, Hunter D, et al. Fish and omega-3 fatty acid intake and risk of coronary heart disease in women. 
JAMA. 2002;287(14):1815-1821.

6. Lemaitre RN, King IB, Mozaffarian D, Kuller LH, Tracy RP, Siscovick DS. n-3 Polyunsaturated fatty acids, fatal ischemic heart disease, and nonfatal myocardial infarction in older adults: the Cardiovascular Health Study. Am J Clin Nutr. 2003;77(2):319-325.

7. Burr ML, Fehily AM, Gilbert JF, Rogers S, Holliday RM, Sweetnam PM, Elwood PC, et al. Effects of changes in fat, fish, and fibre intakes on death and myocardial reinfarction: diet and reinfarction trial (DART). Lancet. 1989;2(8666):757-761.

8. Dietary supplementation with $n-3$ polyunsaturated fatty acids and vitamin $\mathrm{E}$ after myocardial infarction: results of the GISSI-Prevenzione trial. Gruppo Italiano per lo Studio della Sopravvivenza nell'Infarto miocardico. Lancet. 1999;354(9177):447-455.

9. Hirai A, Terano T, Hamazaki T, Sajiki J, Kondo S, Ozawa A, Fujita T, et al. The effects of the oral administration of fish oil concentrate on the release and the metabolism of [14C]arachidonic acid and [14C] eicosapentaenoic acid by human platelets. Thromb Res. 1982;28(3):285-298.

10. Okuda Y, Kawashima K, Sawada T, Tsurumaru K, Asano M, Suzuki S, Soma M, et al. Eicosapentaenoic acid enhances nitric oxide production by cultured human endothelial cells. Biochem Biophys Res Commun. 1997;232(2):487-491.

11. Terano T, Shiina T, Tamura Y. Eicosapentaenoic acid suppressed the proliferation of vascular smooth muscle cells through modulation of various steps of growth signals. Lipids. 1996;31(Suppl):S301-304.

12. Kawano H, Yano T, Mizuguchi K, Mochizuki H, Saito Y. Changes in aspects such as the collagenous fiber density and foam cell size of atherosclerotic lesions composed of foam cells, smooth muscle cells and fibrous components in rabbits caused by all-cis-5, 8, 11, 14, 17-icosapentaenoic acid. J Atheroscler Thromb. 2002;9(4):170-177.

13. Eslick GD, Howe PR, Smith C, Priest R, Bensoussan A. Benefits of fish oil supplementation in hyperlipidemia: a systematic review and meta-analysis. Int $\mathrm{J}$ Cardiol. 2009;136(1):4-16.

14. Giacco R, Cuomo V, Vessby B, Uusitupa M, Hermansen K, Meyer BJ, Riccardi G, et al. Fish oil, insulin sensitivity, insulin secretion and glucose tolerance in healthy people: is there any effect of fish oil supplementation in relation to the type of background diet and habitual dietary intake of n-6 and n-3 fatty acids? Nutr Metab Cardiovasc
Dis. 2007; 17(8):572-580

15. Griffin MD, Sanders TA, Davies IG, Morgan LM, Millward DJ, Lewis F, Slaughter S, et al. Effects of altering the ratio of dietary n-6 to n-3 fatty acids on insulin sensitivity, lipoprotein size, and postprandial lipemia in men and postmenopausal women aged 45-70 y: the OPTILIP Study. Am J Clin Nutr. 2006;84(6):1290-1298.

16. Brostow DP, Odegaard AO, Koh WP, Duval S, Gross MD, Yuan JM, Pereira MA. Omega-3 fatty acids and incident type 2 diabetes: the Singapore Chinese Health Study. Am J Clin Nutr. 2011;94(2):520-526.

17. Villegas R, Xiang YB, Elasy T, Li HL, Yang G, Cai H, Ye F, et al. Fish, shellfish, and long-chain n-3 fatty acid consumption and risk of incident type 2 diabetes in middle-aged Chinese men and women. Am J Clin Nutr. 2011;94(2):543-551.

18. Djousse L, Gaziano JM, Buring JE, Lee IM. Dietary omega-3 fatty acids and fish consumption and risk of type 2 diabetes. Am J Clin Nutr. 2011;93(1):143-150.

19. van Woudenbergh GJ, van Ballegooijen AJ, Kuijsten A, Sijbrands EJ, van Rooij FJ, Geleijnse JM, Hofman A, et al. Eating fish and risk of type 2 diabetes: A population-based, prospective follow-up study. Diabetes Care. 2009;32(11):2021-2026.

20. Djousse L, Biggs ML, Lemaitre RN, King IB, Song X, Ix JH, Mukamal KJ, et al. Plasma omega-3 fatty acids and incident diabetes in older adults. Am J Clin Nutr. 2011;94(2):527-533.

21. Akinkuolie AO, Ngwa JS, Meigs JB, Djousse L. Omega-3 polyunsaturated fatty acid and insulin sensitivity: a meta-analysis of randomized controlled trials. Clin Nutr. 2011;30(6):702-707.

22. Wallin A, Di Giuseppe D, Orsini N, Patel PS, Forouhi NG, Wolk A. Fish consumption, dietary long-chain n-3 fatty acids, and risk of type 2 diabetes: systematic review and meta-analysis of prospective studies. Diabetes Care. 2012;35(4):918-929.

23. Zheng JS, Huang T, Yang J, Fu YQ, Li D. Marine N-3 polyunsaturated fatty acids are inversely associated with risk of type 2 diabetes in Asians: a systematic review and meta-analysis. PLoS One. 2012;7(9):e44525.

24. Wu JH, Micha R, Imamura F, Pan A, Biggs ML, Ajaz O, Djousse L, et al. Omega-3 fatty acids and incident type 2 diabetes: a systematic review and meta-analysis. $\mathrm{Br} \mathrm{J}$ Nutr. 2012;107(Suppl 2):S214-227. 